\title{
Allied Health - 3001. Does treatment of gasteroesophageal reflux disease in patients with allergic rhinitis improve allergic symptoms?
}

\author{
Reza Faridhosseini ${ }^{1}$, Farahzad Jabbari ${ }^{1}$, Afshin Shirkani ${ }^{2 *}$, Mohammad Reza Zandkarimi ${ }^{1}$, Hadis Yousefzadeh ${ }^{3}$ \\ From 2nd WAO International Scientific Conference (WISC 2012) \\ Hyderabad, India. 6-9 December 2012
}

\section{Background}

Allergic rhinitis is the most type of allergic disease among population. Its accurate treatment is very important for cutting off allergic Marche. In the other hand, gasteroesophageal reflux disease (GERD) is one of the most gastrointestinal problems among allergic patients like asthma that it might be the treatment conflict. Despite of asthma, we have a few studies about impacts of GERD treatment on symptoms of allergic rhinitis. In this study we evaluated the correlation of GERD treatment and its effects on improvement of allergic rhinitis.

\section{Methods}

This simple randomized single-blind study included 101 patients with moderate to severe allergic rhinitis. Their allergy for aeroallergens was confirmed by skin prick test considered three $\mathrm{mm}$ more than negative control. Thirty three of 101 patients (32\%) had GERD. For these patients empirically was prescribed $20 \mathrm{mg}$ omeprazol once daily for 6 weeks. Allergic and GERD symptoms evaluated clinically in 5, 10 and 30 days after beginning of treatment.

\section{Results}

Our patients included 48 (46.6\%) male and 55 (53.4\%) female with mean age $28 \pm 11.6$ years old. Thirty one of 33 allergic patients by GERD (mean age; $32 \pm 11.21$ years old) after 6 weeks treatment with omeprazol developed significant improvement for GERD symptoms in 5, 10 and 30 days after beginning of therapy. There was no association between allergic symptoms of these patients and rate of anti-allergic drug consumption $(\mathrm{P}>0.05)$.

${ }^{2}$ Mashhad University of Medical Science, Iran

Full list of author information is available at the end of the article

\section{Conclusions}

This study showed that there was no correlation between empirical treatment of GERD and improvement of allergic symptoms in patients with allergic rhinitis. However further studies with more sample size might be need.

\section{Author details}

${ }^{1}$ Allergy Research Center, Faculty of Medicine, Mashhad University of Medical Science, Mashhad, Iran. ${ }^{2}$ Mashhad University of Medical Science, Iran.

${ }^{3}$ Student Research Assembly of Mums, Mashhad University of Medical Science, Mashahd, Iran.

Published: 23 April 2013

doi:10.1186/1939-4551-6-S1-P178

Cite this article as: Faridhosseini et al:: Allied Health - 3001. Does

treatment of gasteroesophageal reflux disease in patients with allergic rhinitis improve allergic symptoms? World Allergy Organization Journal 2013 6(Suppl 1):P178.
Submit your next manuscript to BioMed Central and take full advantage of:

- Convenient online submission

- Thorough peer review

- No space constraints or color figure charges

- Immediate publication on acceptance

- Inclusion in PubMed, CAS, Scopus and Google Scholar

- Research which is freely available for redistribution 